\title{
Ai, se eu te pego! Viroses, contaminação, cançáo e instantaneidade midiática ${ }^{1}$
}

\author{
Heloisa de A. Duarte Valente \\ Universidade Paulista / Universidade de São Paulo | Orcid: 0000-0002-3250-6722
}

\begin{abstract}
Resumo:
Este texto aborda os processos de difusão e nomadismo da canção, a partir de circunstâncias tais como elementos notadamente musicais, de imaginário, semânticos, mecanismos de difusão da canção de sucesso e o papel das diversas mídias, sobretudo a internet, a fim de garantir sua longevidade. Partese do conceito de "cançáo das mídias" para caracterizar a natureza da canção em análise, apoiada pelo instrumental teórico desenvolvido por R. Murray Schafer (2011), os conceitos de performance (ZUMTHOR, 1997) e consideraçóes de Sacks sobre vermes de ouvido (2007). Como estudo de caso, tomo a canção $A i$, se te pego!, interpretada pelo cantor Michel Teló, estabelecendo uma analogia metafórica entre megassucesso e pandemia.
\end{abstract}

Palavras-chave: Canção das mídias, Nomadismo, Memória da mídia, Performance, Michel Teló.

\section{Ob! If I Catch You! Viruses, Contamination, Song, and Media Instantaneity}

Abstract:

This text analyzes the processes of broadcasting and nomadism of song, under circumstances such as particular musical elements, the imaginary, semantic constructions, diffusion mechanisms of hit song and the function of media, especially the Internet, to ensure its longevity. The departing point are the concepts of "media song" to characterize the nature of the song under consideration, supported by the theoretical apparatus developed by R. Murray Schafer (2001), the concepts of performance (Zumthor, 1997) and reflections about earworms, by Sacks (2007). As a case study case, I take the song "Ai, se eu te pego!" performed by singer Michel Teló, establishing a metaphorical analogy between mega hit and pandemia.

Keywords: Media song, Nomadism, Media memory, Performance, Michel Teló.

\section{Ay! Si yo te agarro! Virus, contaminación, canto y instantaneidad mediática}

\section{Resúmen:}

Este trabajo aborda los procesos de difusión y nomadismo de la canción, a partir circunstancias, tales como determinados elementos musicales de imaginario, relaciones semánticas, mecanismos de difusión de la canción hit y el papel de los medios de comunicación, especialmente la Internet, para garantizar su duración. Partiendo del concepto de "canción de los medios" para caracterizar la naturaleza de la canción en cuestión, apoyados en herramientas teóricas desarrolladas por R. Murray Schafer (2001), los conceptos de performance (ZUMTHOR, 1997) y aportes de Sacks (2007) sobre los gusanos del oido (2007). Como estudio de caso, tomo la canción “Ai, se te pego!", interpretada por el cantante Michel Teló, estableciendo una analogía entre la pandemia y suceso musical. Teló.

Palabras Clave: Canción de los medios, Nomadismo, Memoria de los medios, Performance, Michel

1 A versão inicial deste texto foi publicada no CISC 20 anos: comunicação, cultura e mídia, organizado por Diogo Andrade Bornhausen, Jorge Miklos, Mauricio Ribeiro da Silva. São José do Rio Preto: Bluecom Comunicação, 2012. O que ora apresento traz algumas novas reflexôes sobre o imaginário do "vírus" e sua propagação, tendo em conta a pandemia gerada pelo COVID -19.

ICTUS Music Journal vol. 15 n.1 


\section{1. $S_{\text {obre micróbios, aderências e vínculos }}$}

Viralizou? O verbo já se popularizou e se refere, a princípio, a qualquer tipo de informação, verídica ou falsa, que se alastra instantaneamente. Ocorreu-me retomar um estudo em que as ideias de vínculo de afeto ${ }^{2}$, hábito e aderência se relacionavam de modo similar ao que se verifica desde os primeiros meses de 2020 e que não para de se multiplicar, desdobrando-se em variantes, sem trégua, há mais de um ano - a despeito do surgimento de vacinas: Uma pandemia sem precedentes. Em fins de 2011 e começos de 2012, foi a eclosão do vírus H1N1, portador da gripe suína. Anos antes, em 2003, o Coronavírus SARS, antecessor do doravante designado COVID $19^{3}$, colocava o mundo em polvorosa e as autoridades médicas permaneceram em estado de atenção ${ }^{4}$.

Encontrei semelhanças entre a forma de disseminação da virose e o sucesso da canção de autoria de Michel Teló Ai, se te pego! Tivesse Teló lançado sua canção não na eclosão do vírus H1N1, mas em 2020, poder-se-ia traçar o mesmo paralelo? No que diz respeito à disseminação da informação, certamente a resposta é afirmativa. A natureza de redes de comunicação digital se ampliou, assim como a quantidade de usuários que, por sua vez, póem-se em comunicação ininterrupta. Ademais, mecanismos da inteligência artificial atuam no sentido de fazer com que os dados circulem, a despeito das intençóes do usuário.

É fato que a música e os músicos que a praticam são capazes de estabelecer fortes vínculos não apenas de natureza comunicativa, mas também afetiva. Destaca o teórico Norval Baitello Jr. que a palavra vínculo tem sua raiz etimológica no latim vinculume, designando laço, liame, algemas, prisão, ganhando outras acepções mais abrangentes e abstratas, ao longo da história, designando ligação, elo, relação. Nos termos da semiótica da cultura - sobre a qual se assenta este trabalho-, vínculo pode ser entendido como "o resultado de açôes (inatas ou aprendidas) do ser vivo que o aproximam do outro ou reforçam e alimentam uma proximidade já existente" (BAITELLO JUNIOR, 2009, p. 458).

Ao retomar o vultuoso sucesso de Michel Teló e comparar a sua forma de alastramento ao processo de propagação viral, algumas coincidências - que, de acordo com a leitura, podem ser consideradas ofensivas, até - revelam-se particularmente interessantes, se as analisarmos à luz dos conceitos da semiótica da cultura e da mídia.

Antes de prosseguir, vale destacar que, para além da linguagem figurada, o ato de "pegar" o vírus está infalivelmente ligado à imunidade biológica. No caso de "ser pego" por uma peça musical, concorrem elementos inerentes ao funcionamento do cérebro, que ocorrem de maneira não-intencional, mas também podendo ocorrer deliberadamente. "Pegar" também se aproxima da ideia de "aderência", capacidade de fixação. No caso do COVID-19, sabe-se que depende das espículas de proteína de sua capa externa para penetrar na célula humana e daí, então, poder se replicar. O micróbio é, pois, grudento, pegajoso... Essa forma de existência que parasita outros seres vivos, reduz a humanidade e outras espécies à servidão - assim como, sob certo aspecto, as majors e suas estratégias agressivas. Ao fim e

2 A palavra adota concepções distintas. Para fins deste estudo, entendemos relaçôes de sentimento - as paixôes - quer de aproximação ou repulsa - as diversas nuanças entre amor e ódio.

3 O Coronavírus ocasiona à síndrome respiratória aguda grave (SARS-CoV ou SARS-CoV-1), a síndrome respiratória aguda grave (SARS, conhecida como SRAG, em português). Fonte: Wikipedia.

4 O portal G1 publica pesquisa da Agência Estado, que contabiliza 120 mortes em aproximadamente seis meses $(\mathrm{G} 1,2012)$ 
ao cabo, observam-se mudanças contundentes na paisagem sonora 5 .

\section{Ai, se en te pego... Vírus ou vermes?}

No dia 26 de março último, o crítico e biógrafo Ruy Castro voltava a escrever para a sua habitual coluna da página dois do jornal Folha de S. Paulo. Sob o título Ameaças virais, inicia o texto abordando as diversas acepçóes que vêm sendo aludidas ao termo viral. Ele mesmo, convalescente de uma encefalite que o deixou afastado do trabalho por algumas semanas, não se furta de comentar o sucesso retumbante do cantor Michel Teló e seu hit $A i$, se eu te pego. Procede, entấo, a uma gênese do que seriam as últimas campanhas virais "algo que se espalha pelas redes sociais, como um vírus de gripe que se pega no ar e também atinge milhóes" (CASTRO, 2012, p. 2). Ao publicar o texto o colunista enumerava, uma marca de 80000000 de acessos à canção, pela internet, logo depois de descoberta pelo craque lusitano Cristiano Ronaldo. Ao final, da coluna, pontifica: "Hoje, não há mais celebridades boas ou más, há apenas celebridades-, provocando confusão" (CASTRO, 2012, p. 2).

Embora todas as transposiçóes metafóricas que se façam a músicas que "penetram na cabeça, tocando sem parar" de maneira contínua e implacável sejam relativas aos vírus e bactérias, em termos médicos a associaçáo acabou sendo atribuída aos vermes. Em termos de imaginário, é difícil avaliar qual das referências ganha em provocar repugnância ou medo: de um lado, os vírus, invisíveis, propagados pelo ar, rapidamente; de outro, seres rastejantes, muitas vezes visíveis ao olho nu; palpáveis, gosmentos, grudam na pele. Imaginá-los no interior do cérebro é aterrador... Como observaremos adiante, as alusóes à propagação da informação sonora (música, ou trechos dela, em geral) adotarão pelo senso comum a metáfora do micróbio que se difunde pelo ar, que contamina multidóes, ao passo que a música se aloja individualmente no cérebro humano, terá, como correspondente, os viscosos vermes.

$\mathrm{O}$ fenômeno de repetição incessante de um fragmento musical que existe somente na memória ultrapassa o exercício de paciência, atingindo, em algumas vezes, um viés patológico. São geralmente uns três ou quatro compassos, que martelam os ouvidos, por dias seguidos. Os jingles publicitários são concebidos para, desse modo, atuarem no cérebro: “(...) a indústria da música cria-os justamente para 'fisgar' os ouvintes, para 'pegar' e 'não sair da cabeça', introduzir-se à força pelos ouvidos ou pela mente como uma lacraia”, adverte o neurologista Oliver Sacks (2007, p. 51). Segundo ele, a expressão surgiu inicialmente em alemão (ohrwurm), em 1980, tendo-se estendido à língua inglesa (earworm) ${ }^{7}(2007$, p. 52).

5 A expressão paisagem sonora (adaptação do neologismo soundscape) refere-se ao meio-ambiente acústico, não importan do sua natureza (SCHAFER, 2001).

6 As outras campanhas virais difundidas na internet foram um filme de trinta minutos sobre o terrorista ugandense Joseph Kony, postado no YouTube e a saga de Luísa, aquela que foi ao Canadá, sabe-se lá para o que fazer...Ironiza, a seguir, o crítico: "Não me surpreenderá se uma próxima campanha viral envolver o casamento de Luísa com Cristiano Ronaldo ou o sequestro de Michel Teló por Joseph Kony para fins imorais" (CASTRO, 2012, p. 2).

7 De acordo com Sacks, James Kellaris, pesquisador de Marketing da Universidade de Cincinnati, popularizou o conceito. A ideia, porém, é antiga: "Já na década de 1920, Nicholas Slonimsky, compositor e musicólogo estava deliberadamente inventando formas ou frases musicais que pudessem fisgar a mente e forçá-las à imitação e à repetição. E em 1876 Mark Twain escreveu um conto (...), depois reintitulado Punch, Brothers, punch, no qual o narrador se vê indefeso diante de algumas 'rimas bem cadenciadas' (...) Dois dias depois, o narrador encontra um velho amigo, um pastor, e inadvertidamente o infecta com a música” (2007, p. 52-53). 
Diagnostica-se um verme de ouvido pela sua forma de ação e de contágio, que se dá de acordo com o grau de exposição à peça musical que afeta a vítima. Elementos repetitivos, renitentes na obra facilitam uma replicação sucessiva: são os antígenos provocadores do estado de desestabilidade orgânica. Some-se a isso o fato de que o contágio pode-se dar de maneira fortuita. Lembra Sacks:

Os brainworms costumam ser estereotipados e invariáveis. Tendem a ter certa expectativa de vida, atuando a todo vapor durante horas ou dias e depois desaparecendo, com exceção de alguns 'espasmos' residuais. No entanto, mesmo quando parecem ter sumido, tendem a manter-se à espreita: permanece uma sensibilidade exacerbada, de modo e que um ruído, uma associação, uma referencia a ele pode tornar a desencadeá-los, às vezes anos depois. E são sempre fragmentários. Todas essas qualidades são familiares para muitos epileptologistas, pois elas lembram acentuadamente o comportamento de um pequeno foco epletogênico de início súbito que irrompe, convulsiona-se e por fim se aquieta, mas fica sempre pronto para reanimar-se (SACKS, 2007, p. 55).

O que o estudo dos vermes ou vírus musicais tem de instigante é, justamente o modo como as relaçóes entre memória e música se estabelecem, no cérebro humano. O que a semiótica da música prega, conceitualmente, pode assim ser explicado, pela neurologia:
Alguns atributos das imagens mentais musicais e da memória musical não têm equivalentes na esfera visual e esse fato pode nos dar um vislumbre do modo fundamentalmente diferente de como o cérebro trata a música e a visão. Essa singularidade da música talvez se deva, em parte, à necessidade que temos de construir um mundo visual para nós, daí resultando que um caráter seletivo e pessoal impregna nossas memórias visuais desde o início. As músicas, em contraste, já recebemos construídas. Uma cena visual ou social pode ser cons- truída ou reconstruída de inúmeros modos distintos, mas a recordação de uma música tem de assemelhar-se ao original. É claro que ouvimos seletivamente, com diferentes interpretaçóes e emoçóes, mas as características musicais básicas de uma composiçáo - o tempo, o ritmo, os contornos melódicos, e até mesmo o timbre e o som- tendem a ser preservados com notável exatidão (SACKS, 2007, p. 56)

No caso de uma canção de grande sucesso, ou em uma peça publicitária, as associaçóes que a música estabelece com o objeto ao qual se relaciona (a própria música, um produto a ser vendido etc.) vinculam-se diretamente às emoçóes e sentimentos. Dependendo da natureza destes vínculos, os mecanismos de reiteração, a longevidade da obra musical tende a ser mais efetiva.

No caso dos vermes musicais pode-se mesmo dizer que a despeito da inconveniência, há pessoas que tenham se interessado no assunto, mesmo como gracejo, deleite ingênuo de alguns. Exemplo disso é a página na internet "O verme musical do dia". ${ }^{8}$

8 http://earwurm.com. A página inclui um "Guia definitivo dos vermes de ouvido", com um amplo leque de verbetes. Consulta em 27 mar 2012. Uma nova consulta remete a outras fontes explicativas (https:// creativehero.es/earwurm/), mas a página citada não pôde ser localizada. Com a crescente preferência pelo plataforma Youtube, verificam-se várias coletâneas, organizadas por DJ Earworm: Time of Our Lives: Songs from EVERY YEAR (1970-2020), compiladas em 17 dez. 2020, com 13.000 consultas; DJ Earworm Mashup - United State of Pop 2020 (Something to Believe In. https://www.youtube.com/watch?v=9zQXAAGhZVQ, ), com 19000 consultas. Dados colhidos em 9 mai. 2021 


\section{Assim, você me mata? A contaminação sígnico-musical.}

$\mathbf{E}_{\mathrm{m}}$ uma revista recente, cujo tema central aborda as relaçốes entre as catástrofes do mundo contemporâneo e os processos comunicacionais, chama especial atençáo o texto de Kátia Lerner e Pedro Gradella. Utilizando-se da noção de discurso - este entendido como "(...) conjunto de textos articulados numa prática discursiva”, processo comunicativo e, ao mesmo tempo, prática social (LERNER; GRADELLA, 2011, p. 34) - os autores analisam como se construíram as narrativas na imprensa carioca, desde o aparecimento do vírus Influenza $\mathrm{H} 1 \mathrm{~N} 1$, sua propagação até sinais mais contundentes de alerta, durante o ano de 2009. O artigo identifica como sentimentos de insegurança e medo foram paulatinamente urdidos, em face de uma ameaça de pandemia, atitudes tomadas pela populaçáo e pelo poder público; os sentidos e o sentimento de ameaça, perigo, diante do novo. De fato, a desinformação parece constituir o maior motivo de preocupação e insegurança, uma vez que a luta se trava com o desconhecido. Nestas condiçōes, o trampolim para o temor é iminente.

Segundo a Organizaçáo Mundial de Saúde, desde o surgimento de uma nova doença, seu pico - a epidemia, ou pandemia- até a sua erradicação, há algumas fases, assim caracterizadas:

- Fase 1: Nenhum novo subtipo de vírus de gripe foi descoberto em humanos.

- Fase 2: Nenhum novo subtipo de vírus de gripe foi descoberto em humanos, mas uma doença, variante animal ameaça os humanos.

- Fase 3: Infecção (humana) com um subtipo novo mas nenhuma expansão de humano para humano.

- Fase 4: Pequeno(s) foco(s) com transmissão de humano para humano com localização limitada.

- Fase 5: Maior(es) foco(s) mas expansão de humano para humano ainda localizado.

- Fase 6: Pandemia: aumenta a transmissáo contínua entre a população geral.

Fonte: Wikipedia ${ }^{9}$

A ignorância gera sentimentos de impotência e leva muita gente a adotar mecanismos de proteção, como os escudos os mais diversos (das máscaras respiratórias, unguentos e geleias) até a clausura, o encastelamento em seus lares. Assepsia, desinfecção, distanciamento físico estão algumas das medidas que, a princípio, poderiam conter o avanço do mal que, impiedosamente, acomete suas vítimas sem lhes possibilitar qualquer defesa. Trata-se, pois, de uma guerra do mundo dos micróbios contra os gigantes e desamparados seres humanos...

Ao se mencionar doenças que ganharam o mundo de forma arrasadora, nos últimos cem anos, vem logo à mente a alcunhada gripe espanhola, que acometeu o hemisfério norte todo durante a primavera de 1918 e em particular, as pessoas joven $s^{10}$. Durante a Primeira Guerra, os acampamentos militares foram alvos fáceis: o ato de juntar vários soldados

$9 \quad$ http://pt.wikipedia.org/wiki/Pandemia. Último acesso em 9 mai. 2021.

10 A Primeira Guerra ainda não havia acabado. A doença, que não ultrapassava os três dias rapidamente desapareceu, retornando em agosto, em escala mundial. O que tinha de diferente: não acometia os mais fracos (crianças e velhos), mas jovens entre vinte e trinta anos. Afora os sintomas de praxe, a face ficava roxa, resultado das secreçóes nos pulmóes. O doente acabava afogado nos próprios fluidos. Fonte: http://pt.wikipedia.org/ wiki/Gripe espanhola, acesso em 9 mai. 2021. 
numa só tenda, propiciou a contaminação em larga escala. ${ }^{11}$ Ao longo do século XX, outras doenças colocariam o mundo em pânico, tais como a gripe asiática (1957-1958), a gripe suína $(1976 ; 2009)$, também conhecida como Influenza A H1N1, objeto de estudo do citado texto de Lerner e Gradella. O efeito devastador e letal das doenças transmitidas pelos micróbios levou à criação de analogias com o mundo computacional, como os vírus de computador e sua profilaxia, com vacinas (programas de remoção). Transmitidos geralmente pela rede de computadores, tornaram-se um dos motivos de ansiedade e preocupação do cidadão comum desde final do século XX, uma vez que a comunicação pela web tornou-se indispensável para a maioria das atividades cotidianas.

Não obstante toda a simbologia negativa relacionada à transmissão de doenças e, mais ainda à ideia de contaminação, percebe-se não raro, em alguns setores, uma acepçáo contrária, que lhe confere um status altamente favorável: são os gritos e as coqueluches que importam as novidades da moda, as formas de comportamento social e... musical. Aqui entra, pois, o estudo de caso: $\mathrm{O}$ hit de Michel Teló e sua transmissão pandêmica pela mídia, trazendo, assim, um problema interessante aos estudos musicológicos e comunicativos.

E como isso funciona? De certa maneira, a fórmula já é conhecida: promoção pela gravadora, anúncios, temporadas de shows no Brasil e no exterior, entrevistas nos canais de televisão, matérias na imprensa etc. No presente caso, uma eficiência na utilização das denominadas mídias sociais demonstra otimizar a eficiência comunicativa: blog atualizado, vídeos no Youtube, postagens no Twitter. Um exemplo disso é a ideia de, antes de entrar em cena, no Domingão do Faustão, seu intérprete ter lançado uma mensagem no microblog avisando o momento exato. $\mathrm{O}$ uso das mídias sociais de modo muito bem planejado revela seu potencial na disseminação da informação e, no caso, no alastramento do sucesso da canção- especialmente numa típica canção das mídias (VALENTE, 2003). ${ }^{12}$

$\mathrm{O}$ uso das mídias sociais também se retroalimenta, à medida que se transpóe para o próprio conteúdo das composiçóes: a referência a situações comunicativas corriqueiras quando do uso do telefone celular e outros companheiros eletrônicos portáteis da juventude, no próprio ambiente dos shows, tal é o caso da canção Beijo, me liga - algo que Teló ouviu das espectadoras.

\section{Ai, se eu te pego... Por que me escapas? (A movência da canção).}

A disseminação da canção $A i$, se eu te pego espalhou-se em escala planetária: seu histórico é de muitas transformaçóes, processos de movência. Antes de prosseguir, vale elucidar que o conceito, elaborado pelo erudito Paul Zumthor (1997), refere-se aos processos de tradução e (re)apropriação dos signos poéticos; no processo de suas camadas semânticas sucessivas, o signo (no caso, musical), garante a sua longevidade. Para conhecer um pouco acerca dos antecedentes da obra até seu sucesso na mídia cabe uma breve digressão a respeito de sua gênese. Permito-me citar o antropólogo Hermano Vianna, que revela conhecer todos

11 Segundo estimativas, a gripe espanhola matou entre 20 e 100.000 .000 de pessoas. Comparativamente ao número de mortos da $1^{\text {a }}$ Guerra cerca de 9.200 .000 em combate, 15.000 .000 no total, a 2a Guerra Mundial exterminou 16.000.000 de vidas. Fonte: http://pt.wikipedia.org/wiki/Gripe espanhola. Acesso em 9 mai. 2021.

12 O conceito aqui se refere às canções que já foram concebidas para circular pelas mídias as mais diversas, como também aquelas que podem adaptar-se a elas, da cançáo composta para o sucesso às tradicionais, árias de ópera etc. 
os meandros desta canção perambulante.

Tudo começou no Axé Moi, de Porto Seguro, local descrito em seu próprio site como 'complexo de lazer', ou 'a maior estrutura de praia do Brasil'. (...) Pois bem, o Axé Moi produz espetáculos para entreter os turistas que visitam Porto Seguro. Sharon Acioly foi durante muito tempo a sacerdotisa da diversão no complexo, com várias funçóes, de cantora a animadora. Seu papel ali não era ser protagonista de uma obra de arte; ela precisava manter o público brincando sem parar. Para isso inventava jogos. Um deles virou febre nacional anos atrás. Sharon 'pegou' uma brincadeira trazida para o litoral sul da Bahia por turistas universitários paulistas e mineiros e popularizou a 'dança do quadrado'.

A seguir, Vianna descreve como de brincadeira a quase composição se transformou numa peça funk e como ela foi transformada pelo produtor Antônio Dyggs:

(...) ela [Sharon Acioly] criou um funk para funcionar como trilha sonora do momento em que as turistas sobem ao palco para conferir de perto, pele a pele, os dotes dos dançarinos. (...)De passagem por Porto Seguro, Antônio Dyggs, produtor de baladas de Feira de Santana, foi conferir a animação do Axé Moi. Ficou com o 'ai se eu te pego' na cabeça e resolveu transformar o funk num forró para ser gravado pela Os Meninos do Seu Zeh (...) Apesar de ter ritmo arrastado, a música fez sucesso em várias cidades baianas, chamando a atenção de outras bandas de forró, que lançaram imediatamente suas regravaçóes, cada vez mais animadas. Michel Teló só conheceu seu futuro hit mundial quando ele já fazia parte do repertório da Cangaia de Jegue e da Garota Safada (só para citar as mais conhecidas), botando o povo para dançar e cantar por todo o Nordeste. (VIANNA, 2012).

O relato de Vianna aponta para um processo de transformação constante e ágil, de modo que a canção, sempre fugidia, resiste a uma versão definitiva. Não se consegue pegá-la... Hoje, pode-se até brincar de inventar a mais nova versão da canção... Elas se encontram à disposição do espectador-ouvinte nas mais variadas maneiras paródicas, sérias ou brejeiras, em produçóes amadoras na internet.

Nesse contexto, não se pode deixar de mencionar interesses de outra natureza, como financeiros podem contribuir para um estancamento no processo de movência, tal ocorre com os autodenominados coautores, ou auto-postulados legítimos autores a cobrar os seus direitos intelectuais ${ }^{13}$. Como o sucesso parece ainda não ter chegado ao final, é muito possível que novos coautores ou "verdadeiros autores" ainda se venham dar a conhecer.

\section{Telofonia?}

A esta altura, já parece chacota tentar mais um jogo de palavras...O sobrenome italiano Teló é parônima do grego telos ( $\tau \dot{\lambda} \lambda$ os), que significa alvo, fim, objetivo. A telefonia, teleologia, telepatia nada mais são que vocábulos que agregam em seu sentido a ideia de distância atingida. Michel Teló atingiu o mundo inteiro, maciçamente e de maneira veloz. Os relatos de pessoas cantando o hit são numerosos e, assim que convidei colegas a partici-

13 Tal é o caso das estudantes paraibanas Marcella Quinho de Ramalho, Maria Eduarda Lucena dos Santos e Amanda Borba Cavalcanti, que se dizem coautoras da música. Tendo ingressado com ação contra Teló, obtiveram liminar favorável pelo juiz Miguel de Brito Lyra Filho. Em caso de vitória das reclamantes, elas terão direito a participação nos lucros desde que a música foi gravada até hoje. (O TEMPO, 2012) 
parem da pesquisa ${ }^{14}$, contribuições não cessam de chegar. A título de ilustração, menciono alguns deles. A musicóloga Barbara Alge me enviou o seguinte relato, no dia 6 de março:

Encontrei um vendedor de bilhetes para concertos da Orquestra Mozart (vestido como o próprio Mozart e com peruca) em Viena ouvindo Michel Teló no seu mp3. Ele me falou que era um hit na Itália e na Áustria. Quando voltei para Alemanha no dia 2 de Janeiro de 2012, o hit ainda não tinha chegado aos media da Alemanha, mas duas semanas mais tarde os meus alunos confirmaram a minha previsão: Michel Teló se ouvia na rádio e nas discotecas... e até hoje nenhuma festa sem Teló aqui em Rostock (Norte da Alemanha)

O pesquisador brasileiro Cássio Barth me disse a respeito da repercussão da peça no México, onde reside atualmente: "O interessante é que a música virou tema de introdução para conversas cotidianas para mim aqui no México... 'Tú que eres brasileño, ¿qué significa nossa?' ¿Qué es 'ai se te pego'?' E assim por diante...” Acrescenta que grupos como Calor Norteño e Os Fara Fara já haviam feito suas adaptaçóes, com a letra em espanhol. ${ }^{15}$

A jornalista Juliana Doretto, que vive na República Tcheca, indica-me um filme registrado em seu blog em que crianças cantam e dançam a peça, incluindo o texto em português (sem conhecer o real sentido das palavras...). ${ }^{16}$

Marcello Gabbay, doutorando em estágio de doutorado-sanduíche, apresentou mais que um testemunho auditivo:

Sobre o Michel Teló, posso te garantir que, no Pará, capital e interiores (territórios ainda ferozmente pautados pelo rádio e pela TV), ele estourou sim! Voltei do sanduíche na França em janeiro agora e tenho permanecido na Ilha de Marajó, onde o hit ainda é repetido nas rádios com boa intensidade! Recentemente fui a um aniversário infantil, e a canção do dito cujo foi a mais aclamada entre as crianças de 5 a 10 anos. (...) Mais uma: amigo meu paraense que vive em Israel, também me relatou a ocorrência de "Ai se eu te pego" em inglês e português nas baladinhas locais. Por fim, nos meus últimos dias em Paris, vi no Facebook de um amigo, a versão em francês feita por jovens brasileiros que residem na França, mas esta era meramente amadora e internáutica. ${ }^{17}$

Pelo que mostram as diversas fontes disponíveis na internet, a adesão à canção de Teló é mundial. É possível encontrar versóes as mais diversas, das mais caseiras às mais elaboradas, com produção cuidada: o grupo mexicano El Cielito, o cantor português José Malhoa,

14 Encaminhei a várias listas de discussão o pedido, no dia $1^{\circ}$ de março de 2012: gostaria de saber como o fenômeno se deu, nas diversas localidades nacionais e internacionais. Cito alguns dos nomes de colegas que amavelmente me responderam: Fabiano Lacombe, Juliana Doretto, Marcello Gabbay, Tacyana Arce, Nair Prata, Diego da Rocha, Cássio Barth, Barbara Alge, Evandro Higa, Martha Ulhôa, Álvaro Neder, Wander Nunes Frota, Julio Mendívil, Ayêska Paulafreitas, Camila Bonfim, Carlos Palombini, Sergio Basbaum, Ana Lúcia Moreira. 15 Lista de discussão etnomusicologiabr@yahoogrupos.com.br, 1 mar 2012, 21 h12

16 A matéria assim dispóe: "Parece que a 'praga' chegou à República Tcheca. E atingiu as crianças. Uma professora tcheca, Lucie Tvrdoňová (especializada em Zumba, um programa intenso de ginástica com dança), resolveu criar uma coreografia para seus alunos a partir da canção brasileira. Na apresentaçáo, meninos e meninas esticam os braços e os trazem juntos ao corpo, ao som de Michel Teló proferindo a frase "ai, se eu te pego". E, no final, os garotos e as garotas cantam, em bom português, "Delícia, delícia. Assim você me mata...”. "Na República Tcheca, 'Ai se eu te pego" vira coreografia infantil. Originalmente publicado em: http://cidadesdoleste.com/2012/01/02/na-republica-tcheca-ai-se-eu-te-pego-vira-coreografia-infantil/. Acesso em $1^{\circ} \mathrm{mar}$ 2012. Disponível, atualmente, http://filosomidia.blogspot.com/2012/04/entrevista-com-michel-telo-e-noticia. html. Acesso em 9 de mai 2021.

17 Comunicação por e-mail, $1^{\circ} \operatorname{mar} 2012,12 \mathrm{~h} 41$. 
a versão infantil de Jaciara Gardin, as versões em russo, chinês, japonês... e até pelo Pato Donald! E não será em todos os casos que o texto será compreensível. O que sugere que a música, por si só, já se basta para agradar a um público que extrapola a língua portuguesa.

\section{Epassou a menina mais linda, Tomei coragem e comecei a falar... \\ Como relatam as diversas fontes que têm surgido sobre o tema, parece ter sido} a dancinha do craque Cristiano Ronaldo que catapultou o (já) grande sucesso de Michel Teló. Como e porque se deu o fato, há várias especulaçôes, mais ou menos cuidadosas. O que se pode afirmar, com segurança é que, náo residindo no Brasil, o craque tomou conhecimento da canção por outro meio, quiçá pela internet, alguma aparição na televisão ou, mesmo, o vídeo em DVD (ou blue ray). Havia um conhecimento de natureza visual, porque ele sabia os passos da coreografia. Essa situação curiosa foi repetida por outros astros esportivos e não apenas restritos ao futebol: os tenistas Novak Djokovic, Rafael Nadal, dentre muitos outros, comemorariam suas vitórias com a dança.

A canção acabou por transformar-se em brincadeirinha para comemorar a vitória nos jogos, em diversas situaçóes, tal como folguedo infantil. Aqui, as semelhanças não são casuais, já que, nessas brincadeiras são comuns vozes ditando palavras de ordem, instruçóes, indicando movimentos ou gestos a serem realizados pelo grupo, como bater palmas, dar voltas, pronunciar frases ou interjeiçóes etc. Apesar de alguns movimentos notadamente alusivos ao coito, a grande maioria dos gestos descreve açóes mímicas estereotipadas, acompanhando o texto que, por sua vez, é muito breve e direto; o coloquialismo da letra não despreza os já comuns erros de português (erros comuns de concordância verbal). Desse modo, muito se aproxima das cantigas de roda folclóricas das séries escolares iniciais.

E o que dizer da repercussão ante a imagem de certos astros, midiáticos, como o exitoso Neymar? Dançar a coreografia reitera o seu aspecto juvenil, ao somarem-se à imagem do jovem craque do futebol a molecagem do garoto em idade escolar com o atrevimento adolescente, que sinaliza alguns gestos e micagens de natureza obscena. (A despeito de tudo isso, o craque mostrou-se encabulado e retraído na sua participação no Programa Hebe Camargo, em que dividia o sofá com Michel Teló....)

\section{Sábado, na balada...}

A atualidade de Michel Teló, intérprete e produtor de sua imagem, reside não apenas na demanda social que atende, mas também na maneira como se vale dos recursos midiáticos. O repertório de Teló tem clima de festa, entretenimento da juventude urbana; ademais, seu repertório passou a ser incorporado ao gosto de outras camadas da sociedade que antes rejeitavam gêneros advindos de estratos sociais desfavorecidos monetariamente. Em extensa matéria publicada pela Revista Época, conduzida por Humberto Maia Jr. e Luís Antônio Giron (2012), destaca-se o depoimento do cantor e compositor Marcos Valle:

Essa mesma aproximação aconteceu no mundo do samba com o surgimento do pagode. Muitos sambistas viam aquilo como uma decadência do ritmo, mas depois puderam ver que os pagodeiros ajudaram o samba a chegar a ambientes a que nunca havia chegado, renovando e aumentando o público (2012, p. 56). 
No entender de Heloísa Buarque de Hollanda, estudiosa em cultura contemporânea brasileira, Teló representa um nicho da sociedade que antes não era facilmente percebido e que foi legitimado pela elite, declara à reportagem da Revista: "O interior do Brasil e a periferia urbana - o lugar de chegada de pessoas do campo - ascenderam. Eles influenciam a estética e o consumo de toda a sociedade", fenômeno que repete o que sucedeu com o funk e o pagode. (2012, p.56).

Seguindo esse raciocínio, pode-se encontrar, na canção $A i$, se eu te pego, uma espécie de retrato da sociedade contemporânea. Maia Jr. e Giron, para a Revista Época relatam bem a situação:

O sertanejo universitário rompeu as barreiras sociais, popularizou o estilo nas classes A e B e chegou aos bairros chiques das grandes cidades do país. Ninguém teve tanto sucesso em traduzir os valores populares para os jovens de elite quanto Teló. Tome o exemplo da universitária Stela Medeiros, de 18 anos, moradora de Sáo Paulo. Ela gostava de Lady Gaga e Beyoncé. Passou a ouvir sertanejo depois que a amiga Giovana Volpato, de 17 anos, moradora do Morumbi, bairro nobre de São Paulo, lhe mostrou as músicas de Michel Teló. 'Sempre achei aquela coisa de dor de cotovelo e bota uma coisa muito cafona', diz Stela. 'O estilo do Michel é mais próximo do meu, e a música é de balada.' Também a carioca Isabela Aragáo Coutinho, de 17 anos, filha de advogados e moradora de Laranjeiras, Zona Sul do Rio de Janeiro, divide a memória de seu iPod entre Coldplay, Kate Perry e Teló. 'Ele é supercool', afirma. 'Suas letras são picantes e divertidas, não tem como não gostar dele. $\mathrm{Na}$ balada, todo mundo se levanta quando começa a tocar Michel Teló.' (2012, p. 54).

Como justificativa parcial para o ruidoso sucesso, acrescentaria, ainda, o fato de que a população vem crescendo sem o contato com outro tipo de música não-comercial de maior complexidade composicional (vide-se o abandono, por largos anos, da disciplina Educação Musical no ensino básico). Em assim sendo, o repertório de Teló e seus sucedâneos atende à demanda de maneira satisfatória.

Sob o aspecto musical, pode-se afirmar que, embora não complexa, enquanto composição musical, a obra passa por vários processos de movência ${ }_{s}$ como já mencionado anteriormente. Os mecanismos que constroem e (re)alimentam o sucesso de Michel Teló são vários. Vale tomar alguns desses referenciais, a fim de poder discernir algumas das razóes que justificam o imponente sucesso. Como gênero musical, quase sempre entabulado na categoria sertanejo universitário ${ }^{18}$, o hit escapa a esse atrelamento de maneira direta.

Primeiramente, ressalte-se a confusão que se criou acerca das distinçôes entre música caipira e sertaneja. O etnomusicólogo Evandro Higa ressalta ${ }^{19}$, a esse respeito, que existe uma distinção que passa, antes de qualquer coisa, pelo crivo comercial. Apoiando-se nos

18 De acordo com o historiador Expedito Silva, o forró universitário surgiu a partir de 1975, reestruturando-se no decorrer da década de 1990. O objetivo era promover uma fusão do forró tradicional com o pop e o rock. Para tanto, valeu-se de instrumentos eletrônicos. Aquilo que se designou como forró universitário propriamente dito, despontou na década de 1980, representado por grupos musicais nem sempre do meio universitário, mas ligados ao entretenimento destes. Na década seguinte, uma nova geraçấo tenta uma reaproximação ao forró tradicional, retomando os instrumentos tradicionais. $\mathrm{O}$ espectro é amplo, e inclui desde formaçōes como a Banda Falamansa, Banda Mafuá, Trio Virgulino, Cascabulho, Mestre Ambrósio (dentre outros) no âmbito do Projeto Espaço Cultural Equilíbrio (SILVA, 2003, p..103-104).

19 Os comentários feitos pelo pesquisador surgiram na lista de discussão da Associação Internacional para o Estudo da Música Popular- Seção Latino-americana: (iaspm-al@googlegroups.com) no dia 7 mar. 2012, a partir de uma consulta minha, a respeito das repercussóes regionais e internacionais da canção $A i$, se eu te pego.

ICTUS Music Journal vol. 15 n.1 
estudos do sociólogo José de Souza Martins, Higa identifica a música caipira como sendo "a música sertaneja transformada em mercadoria, perdendo (ou transformando) sua função social ligada ao trabalho, lazer, religiosidade, etc.". A denominada "música caipira de raiz", gravada e comercializada deixaria de ser caipira para se tornar sertaneja.

O sertanejo migrará para a periferia das grandes metrópoles e consumirá não apenas a estética musical, bem como os seus produtos correlatos (vestuário, eventos etc.), à medida que o poder aquisitivo dos receptores cresce, entre as décadas de 1980-90. Parte da burguesia denominará este subgênero como sertanojo. $\mathrm{O}$ denominado sertanejo universitário representa a retomada de "reminiscências da cultura caipira com a cultura jovem globalizada", legitimando "uma música onde o interior do país parece se reconhecer sem culpas e os paradigmas da modernidade parecem se hibridar a uma ruralidade real e/ou recordada", adverte, uma vez mais, Evandro Higa. Essa modalidade terá, dentre seus inúmeros expoentes Luan Santana, a dupla João Bosco e Vinícius, Maria Cecília e Rodolfo e... Michel Teló.

Mas, ao que tudo indica, $A i$, se eu te pego não pertence ao forró, nem à balada sertaneja. Trata-se de uma mistura de vários componentes, agregados de maneira bem estudada. A canção é um compósito de várias outras: há traços do vaneirão, dança de saláo gaúcha derivada da habanera ${ }^{20}$, que migrou para o centro-oeste brasileiro, junto com os sulistas que para a lá migraram, a fim de desenvolver atividade agropecuária (Teló pertence a uma dessas famílias migrantes). Outro aspecto não menos relevante é o cuidado de Teló, ao selecionar os seus músicos acompanhantes. ${ }^{21}$ (É de se supor mesmo que sua formação musical tenha contribuído técnica e intelectualmente no processo de escolha). Como derivado do vaneirão, conserva o destaque para o acordeão, nas passagens de uma estrofe a outra (pontes) e na introdução. A presença do instrumento não é casual: enquanto tocou no Grupo Tradição ${ }^{22}$, Michel Teló era um executante bastante desenvolto, com amplo domínio no seu instrumento.

Ainda a respeito do acordeão - muitas vezes denominado gaita, entre os gaúchosé de se lembrar que se trata de um instrumento muito frequente nas músicas populares tradicionais e folclóricas de muitos países, em várias regiōes do planeta, sobretudo rural. Dessa forma, poderia atuar como um elemento de memória cultural (musical) de tempos anteriores ao surgimento das mídias (e, quem sabe, de um outrora passado rural e feliz, deixado para trás, em tempos de industrialização...)

Por fim, uma última observação: o sucesso $A i$, se eu te pego mistura de vaneirão gaúcho e forró nordestino, num arranjo que inclui a instrumentaçâo da canção pop costumeira. Dança gingada que normalmente leva à fama internacional cantores e dançarinos com traços fisionômicos e corporais acentuadamente mestiços, afrodescendentes. Michel Teló, aloirado, claro, revela bem os traços dos italianos do norte, bastante presentes no sul do Brasil mas que não costumam atingir os píncaros da glória midiática - ao menos no campo da canção midiática. Representa, de algum modo, uma nova feição da brasilidade for export.

20 Vaneirão (ou vanerão), assim como a vaneirinha são danças derivadas da habanera, ou havaneira e possui o característico modelo rítmico sincopado (colcheia pontuada, semicolcheia, colcheia, colcheia).

21 Um dos músicos acompanhantes de Teló era destacado pianista, cuja aptidão, reconhecida imediatamente por Teló, resultou num convite para integrar o seu grupo. Agradeço à professora Ana Lúcia Moreira pelas informaçôes coletadas (comunicaçẫo pessoal, em 14 mar. 2012).

22 Sobre o grupo, consta da sua página na web: "A história do inconfundível batidão do Tradição começou em outubro de 1995, com a criação do grupo pelo então músico e, depois, empresário Wagner Hildebrand. A ideia era formar um grupo capaz de misturar ritmos como chamamé, rasqueado e vanera à música sertaneja e criar algo contagiante, alegre e dançante". Disponível em: http://www.grupotradicao.com.br/historial. Acesso em: 27 mar. 2012. 


\section{Como enfrentar os vermes de ouvido e outros vírus musicais alta- mente resistentes, como o COVID -19 e suas novas cepas? Finale (sem fade out)}

$\mathbf{E}_{\mathrm{m}}$ finais de março de 2012, encerrava a primeira versão deste texto, o hit de Teló permanecia "na boca do mundo", em português (bem ou mal pronunciado) ou traduzido. Os noticiários não deixavam de trazer notas a respeito do sucesso. O boletim independente Wikinotícias, datado de 3 de janeiro de 2012, revelava que, até aquela época, o número de visitas no Youtube já havia ultrapassado os 94000 000. A revista Forbes classificava o hit como "fenômeno na Internet", equiparando-o ao ídolo juvenil Justin Bieber $^{23}$. Mais que um grande sucesso, a canção de Teló apoderou-se de muitas cabeças, não deixando de poupar uma grande parcela da população mundial. Tornou-se um verme de ouvido que se propagou pelo mundo, tal como uma pandemia midiática. Em se tratando de quase uma patologia na paisagem sonora (SCHAFER, 2001) parece razoável que algo seja feito para que o universo acústico possa retomar a sua melodiversidade- se assim podemos inventar uma outra nomenclatura.

Em tempos em que um vírus toma o planeta de assalto, qualquer comentário em tom irônico e mordaz relacionando música e contaminação com poder letal corre o risco de ser mal interpretado, tomado como falta de respeito face aos mais de 420000 mortos, apenas no Brasil e tantos sobreviventes que lutam a cada dia para recuperar a saúde.

De outra parte, é preciso ter especial atenção com relação às dificuldades particulares dos artistas - os primeiros a saírem de cena e os últimos a voltarem - o que somente será possível quando a rotina cotidiana retomar o seu ciclo. Ainda que sob condiçóes bastante adversas, muitos são deles recorrem a novas formas de criação poética e de comunicação com o seu público. Mais que entretenimento, passatempo, diversão para aqueles que aceitaram trancar-se em casa, os artistas estabelecem e sustentam importante vínculo (comunicativo, afetivo) capaz de fazer com que as pessoas que se encontram isoladas possam encontrar maneiras de preservar a saúde física e mental. São sobretudo os certames, os shows que, por meio das plataformas midiáticas transmitem, pelas redes sociais, conteúdos novos que vêm a promover o espírito crítico, o entusiasmo, a força para seguir adiante.

Além destas possibilidades, há o serviço de fornecimento de música remotamente, pelas infovias pelo sistema de streaming. Quase sempre há um oferecimento de um conjunto de repertórios que, segundo algoritmos e grupos classificatórios atende, supostamente, aos gostos pessoais do ouvinte. Ocorre que trilhas musicais de todo tipo tomem a paisagem sonora sem pedir licença, transformando-se em Moozak (música ambiente), até "viralizar na playlist", tornando-se "vermes musicais" ... Como mesmo adverte Sacks (2007), as músicas que grudam na memória são persistentes. Em períodos de vida confinada e em espaços subdimensionados (ou superdimensionados) podem reiterar a sensação de sufocamento e angústia. É quando se faz necessário pôr em prática: a "clariaudiência", conforme preconiza Schafer (2001).

23 http://pt.wikinews.org/wiki/M\%C3\%BAsica_\%22Ai,_Se_Eu_Te_Pego\%22_de_Michel_Tel\%C3\%B3_\%C3\%A9_sucesso_fora_do_Brasil. Último acesso em 9 mai. 2021. Michel Teló passa de 100 milhöes de acessos no Youtube com 'Ai, se Eu te Pego' http://veja.abril.com.br/noticia/celebridades/michel-telo-passa-de100-milhoes-de-acessos-no-youtube-com-ai-se-eu-te-pego. Último acesso em 9 mai. 2021. 


\section{Referências}

BAITELLO JUNIOR, Norval. O pensamento sentado: sobre glúteos, cadeiras e imagens. São Leopoldo: Unisinos, 2012.

. Vínculo. In: MARCONDES FILHO, Ciro. (org.). Dicionário da comunicação. São Paulo: Paulus, 2009. p. 458.

CAMPOS, Rogério de. Exposição traz ao Brasil de J. Carlos. Folha de S. Paulo, São Paulo, 10 abr. 1991. Ilustrada, p.1.

DORETTO, Juliana. Entrevista com Teló é notícia mais vista em telejornal para crianças da Holanda Cidades do Leste. In: SILVA, Leopoldo N. (Leo Nogueira Paqonawta). Filosomidia. Disponível em: http://filosomidia.blogspot.com/2012/04/entrevistacom-michel-telo-e-noticia.html. Acesso em 9 mai. 2021.

LERNER, Kátia; GRADELLA, Pedro. Mídia e pandemia: Os sentidos do mendo na cobertura de Influenza H1N1 nos jornais cariocas. Revista ECO- Pós. Rio de Janeiro, v.14, no 2, pp.;33-54 2011

MAIA Jr., Humberto; GIRON, Luis Antonio. Ai, se eu te pego...Com melodia fácil e letras que falam ao público jovem, o cantor paranaense bateu recordes na internet e traduziu os valores da cultura popular para todos. Época. São Paulo, 2 jan 2012, pp. 50-61.

SACKS, Oliver. Alucinaçóes musicais. Relatos sobre a música e o cérebro. São Paulo: Companhia das Letras, 2007.

SCHAFER, R. Murray. A afinaçáo do mundo. São Paulo: Editora da Unesp, 2001.

SILVA, Expedito L. Forró no asfalto - mercado e identidade sociocultural. São Paulo: Annablume, 2003.

VALENTE, Heloísa. As vozes da canção na mídia. São Paulo: Via Lettera; FAPESP, 2003.

VIANNA, Hermano. "Talvez ninguém mais consiga ter carreira longa e estável fazendo/ tocando música”. In O Globo. http://sergyovitro.blogspot.com/2012/01/hermanovianna-cibercondicao.html Acesso em 10 mar. 2012.

ZUMTHOR, Paul. Introdução à poesia oral. São Paulo: Hucitec; Educ, 1997.

\section{Outras fontes}

O TEMPO. http://www.otempo.com.br/otempo/noticias/?IdEdicao=2341\&IdNoti$\underline{\text { cia }=198240}$. Acesso em 14 mar 2012.

PROGRAMA HeBE CAMARGO. Apresentado por Hebe Camargo. São Paulo: Rede TV, 213 nov. 201122 h. Duração 90 min. Entrevista com Michel Teló e Neymar. 
SARS-CoV. In: Wikipedia. Disponível em: https://pt.wikipedia.org/wiki/SARS-CoV. Acesso em 9 mai. 2021.

Gripe suína já matou mais que em todo o ano de 2011. In: G1- Brasil. Disponível em : http://g1.globo.com/brasil/noticia/2012/07/gripe-suina-ja-matou-mais-que-emtodo-o-ano-de-2011.html. Acesso em 9 mai. 2021. 